\title{
THE ANALYSIS OF FOREIGN-VESSEL SINKING AS AN EFFORT BY THE GOVERNMENT OF INDONESIA TO COMBAT IUU FISHING PURSUANT TO INTERNATIONAL LAW
}

\author{
Kristiyanto \\ Under Graduate Student, International Program \\ Faculty of Law, University of Brawijaya \\ kristiyanto1994@gmail.com
}

\begin{abstract}
As an archipelagic state, Indonesia possesses some of the most abundant fishery resources in the world. Geographically, Indonesia's strategic location makes it a challenge, and it is a shared responsibility for all citizens to preserve and conserve these resources. The strategic location and rich biological as well as non-biological marine resources automatically attract foreign vessels to carry out IUU fishing activities, particularly in the area of ZEEI (Indonesian Exclusive Economic Zone). The Government of Indonesia has taken various preventive measures to combat IUU fishing practices through bilateral cooperations and various laws. In addition, the Government has also taken some repressive efforts by burning and sinking foreign vessels. In this study, the researcher will analyze the governmental action pursuant to international law and examine the extent to which the sinking of the ship is effective from the perspective of international law. This study will be conducted using normative and juridical approach by reviewing and analyzing various national and international legal instruments related to IUU fishing. We hope that this study will be able to deliver theoretical and practical benefits for students and other researchers who are interested in the issue of IUU fishing practices.
\end{abstract}

Keywords : IUU fishing, marine resources, archipelagic state.

\section{INTRODUCTION}

Indonesia is the World's largest archipelagic state, consisting of 13,667 islands. The coastline of Indonesia reaches $95,181 \mathrm{~km}$, with the total of sea area as wide as 5.8 million square-kilometers. So, the vast collective territorial sea of Indonesia is responsible for $80 \%$ of the total area, therefore Indonesia is often referred as an archipelagic state ${ }^{1}$. In the sea area, Indonesia has a wide variety of

\footnotetext{
${ }^{1}$ The island-nation or Archipelagic State is a country that throughout its territory consists of one or more islands, including other islands close its relations with each other, including the waters of these and other natural form, has the sovereign waters are waters archipelago located in the side of the linestraight archipelagic baselines. Mochtar Kusumaatmadja, Introduction to International Law, Alumni, Bandung, 2003, p. 179.
} 
ecosystems such as 8,500 species of fish, 555 species of seaweeds and 950 species of coral reefs, which make Indonesia as the largest mega-biodiversity in the world ${ }^{2}$. Such potential in the field of fishery is an economic capital ${ }^{3}$ that can be utilized as much as possible for the future of the nation as the backbone of national development. This is in accordance with the provisions of article 33, paragraph 3 of the Constitution of the Republic of Indonesia in 1945 which mandates that earth, water and all natural resources contained therein are managed by the state and utilized as much as possible for the people's welfare. However, the abundance of biological wealth has not been able to make a significant contribution to the welfare of the people. It is evident from the number of fishermen who still live below the poverty line. This is due to the limited management and utilization of fish by fishermen, making the situation difficult to overcome poverty. This condition is exacerbated by the

\footnotetext{
${ }^{2}$ Anonymous. INDONESIA HAS THE LARGEST MARINE BIODIVERSITY IN THE WORLD. 2009. (Online:http://kkp.go.id/index.php/arsip/c/9822/KEA NEKARAGAMAN-HAYATI-LAUT-INDONESIATERBESAR-DI-DUNIA/?category_id). Accessed on 15 Mei 2014, at 15.12 WIB.

${ }^{3}$ Lecturer team, Citizenship Education, Field Studies Unit, University of Padjadjaran, Bandung, 2007, p. 135
}

increasingly widespread practice of illegal fishing by fishermen from other countries, or better known as poaching by foreign vessels. These fish thieves may come from foreign countries, to be precise, those with the ability tp utilize the technology and fisheries management so well. Thus in practice, the state greatly is harmed by those activities. At least there are several reasons that underlie the practice of illegal fishing by foreign fishermen ${ }^{4}$ :

1. Fish is a fundamental commodity for all the people and the cost is going to be cheaper if it is acquired by the method of stealing;

2. Opportunities and possibilities of fishery resources to be looted are quite large. In the woods, it is relatively easier to monitor and detect the rampant of illegal logging practices; but the supervising process on the sea is difficult due to its size;

3. No seriousness of the various parties to address illegal fishing practices. Normally, the countries that suffer greater losses due to illegal fishing practices are

\footnotetext{
${ }^{4}$ Dr. Ir. Victor PH Nikijuluw, Socio-economic dimensions of Illegal Fishing (Blue Water Crime), Jakarta, Cidesindo 2008
} 
developing countries, because they have less ability and capacity to oversee and maintain the resources they have.

Due to illegal fishing practices, Indonesia is estimated to have suffered losses between $\$ 3$ billion and $\$ 6$ billion per year. If calculated since 1970-the year when Indonesia proclaimed to open up opportunities for foreign investors to exploit fishery resources in Indonesia-the amount accumulated for over 30 years equals more than US $\$ 209$ billion, or around 2,500 trillion rupiah $^{5}$ in present value (the data obtained in 2008). Illegal fishing carried out by foreign vessels is one of the Blue Water Crime 6 known as the practice of IUU fishing (Illegal, Unreported, Unregulated fishing). Due to the impact of IUU fishing, it causes not only losses of the economic sector, but also the loss of environmental, biological and social sectors.

As one of the ratifying states (state party) in the United Nations Convention on the Law of the Sea (UNCLOS) in 1982, the government of Indonesia made an effort to combat the practice of IUU fishing by

\footnotetext{
${ }^{5}$ Zaqiu Rahman, Sinking Ships In an effort Eradication of Illegal Fishing, rechtsvinding Online

6. Ibid, Page 5
}

issuing Law No. 45 of 2009 on the Amendment of Law No. 31 Year 2004 on fisheries, using UNCLOS 1982 as the basic material ${ }^{7}$. Associated with the sinking of the ship, it is specifically regulated in article 69 paragraph (4), which states: In carrying out the functions referred to in paragraph (1) the investigator and/or fisheries supervisor can perform specific actions such as burning and/or sinking of foreign-flagged fishing vessels based on sufficient preliminary evidence ${ }^{8}$. The effort of sinking the ship is a form of ultimum remedium that can be taken by the government if other efforts failed.

However, the provisions of article 69 paragraph (4) is not in accordance with the provisions of article 76A of Law No. 45 Year 2009 on the Amendment of Law No. 31 Year 2004 on fisheries which require a court decision before the action can be executed. Discrepancy in this would greatly affect the implementation of the field that will ultimately have an impact on the effectiveness of the eradication of the practice of IUU fishing ${ }^{9}$. Inconsistency and discrepancy between national law and

\footnotetext{
${ }^{7}$ Ariatno, Indonesia Interest In Free Marine Fisheries Management, Indonesia Journal of International Law, 2005, 2 (3): 503-544

${ }^{8}$ Provisions of article 69 paragraph (4) Law Number 45 Year 2009

${ }^{9}$ Testimony Associate Lakshman (Ret.) Freddy in ibid. page viii
} 
international law related to criminal sanctions for illegal fishing by foreign vessels, in particular the sanctions related to the sinking of foreign fishing vessels, will complicate the task of the government to eradicate the practice of IUU fishing.

\section{METHODE OF RESEARCH}

This research uses juridicalnormative method, including reviewing and analyzing the rules of national law and international law on the eradication of the practice of IUU fishing. Specifications of this study is more descriptive-qualitative, which in this case takes the critical analysis of some general provisions in the national legal norms and international law related to the setting of IUU fishing in analyzing the object problems. The analysis approach in this research is Statute Approach and Case Approach.

Based on the description of the background and the formulation of the problem above, the purpose of this study are to know the forms of law enforcement in the field of fisheries by the Government of the Republic of Indonesia concerning the practice of IUU Fishing and too determine the extent to which national law enforcement that have been based on various instruments of international law is effective in combating IUU fishing practices.

\section{RESULT AND DISCUSSION}

A. National Action Plan For Preventing And Combating IUU Fishing Implemented by Indonesian Government Based On International Instruments

As the further effort on the various international instruments in the field of IUU fishing, the Indonesian government has made various efforts to follow up the international legal instrument as a national Action Plan for Preventing and Combating IUU Fishing Implemented by Indonesian Government Based on International Instruments ${ }^{10}$

\section{International Instruments}

a. States should give full effect to relevant norms of international law, in particular as reflected in the 1982 UN Convention, in order to prevent, deter and eliminate IUU fishing.

b. States are encouraged, as a matter of priority, to ratify, accept or accede to, as appropriate, the 1982 UN Convention, the 1995 UN Fish Stocks Agreement and the 1993

\footnotetext{
${ }^{10}$ Decree of the Minister of Marine and Fisheries of the Republic of Indonesia Number Kep.50 / MEN / 2012 on National Action Plan on IUU Fishing Measures Period 2012-2016
} 
FAO Compliance Agreement. Those States that have not ratified, accepted or acceded to these relevant international instruments should not act in a manner inconsistent with these instruments.

c. States should implement fully and effectively all relevant international fisheries instruments which they have ratified, accepted or acceded to.

d. Nothing in the IPOA affects, or should be interpreted as affecting, the rights and obligations of States under international law. Nothing in the IPOA affects, or should be interpreted as affecting, the rights and obligations contained in the 1995 UN Fish Stocks Agreement and the 1993 FAO Compliance Agreement, for States parties to those instruments.

e. States should fully and effectively implement the Code of Conduct and its associated International Plans of Action.

f. States whose nationals fish on the high seas in fisheries not regulated by a relevant regional fisheries management organization should fully implement their obligations under Part VII of the 1982 UN Convention to take measures with respect to their nationals as may be necessary for the conservation of the living resources of the high seas.

Indonesia adheres to the norms of international law relating to the management of fishery resources in an orderly and responsible way, including the prevention and control of IUU fishing, among others, by the legalization of these following laws:

1) Law No. 5 of 1983 on the Indonesian Exclusive Economic Zone (ZEEI);

2) Law No. 17 of 1985 on Ratification of the United Nations Convention on the Law of the Sea;

3) Law No. 31 of 2004 on Fisheries, as amended by Law No. 45 of 2009; and

4) Law No. 21 of 2009 on Ratification towards Agreement for the Implementation of the Provisions of the United Nations Convention on the Law of the Sea of 10 December 1982 Relating to the Conservation and Management of Straddling Fish Stocks and Highly Migratory Fish Stocks

As a consequence to follow-up the approval or ratification of the Convention and/or international treaties, Indonesia has adjusted the legislation on fisheries, including adopting the provisions of CCRF into various provisions of national law, and actively participated in Regional 
Fisheries Management Organizations (RFMOs).

\section{Indonesia action Plans:}

1. Continue the process of ratification of the FAO Compliance Agreement in 1993;

2. Continue the accession process to the WCPFC;

3. Continue the process of ratification of the Port State Measures;

4. Continue the integration process of RFMOs resolution into national legislation;

5. Participate actively in RFMOs activities, including implementation of the resolution and capacity building;

6. Renew authorized fishing vessel and record of fishing vessel;

7. Complement legislations and guidelines for the implementation of international instruments.

\section{National Legislations}

\section{a. National Regulations}

Recommendation of IPOA-IUU Fishing

$$
\begin{aligned}
& \text { 1. National legislations } \\
& \text { should address in an }
\end{aligned}
$$

effective manner all aspects of IUU fishing.

2. National legislations should address, inter alia, evidentiary standards and admissibility including, as appropriate, the use of electronic evidence and new technologies.

Indonesia has revised Law No. 31 of 2004 on Fisheries, by Act No. 45 of 2009, in an effort to improve:

1. Effectivity of management and conservation of fish resources;

2. Implementation of sustainable fisheries development; and

3. Accommodation of the strategic environment development, both regionally and globally. In addition, Indonesia has developed a number of public policies, including:

- Government Regulation No. 24 of 2006 on Appointment and Dismissal Procedures for Ad Hoc Court Judge Fisheries; 
- Presidential Decree No. 15 of 2010 regarding the establishment of the Court Fishing in Tanjung Pinang District Court and Ranai District Court;

- Decree of the Minister of Marine Affairs and Fisheries No. KEP.58 / MEN / 2001 on Procedures for the Implementation of Public Monitoring System in Management of Marine Resources and Fisheries;

- Regulation of the Minister of Marine Affairs and Fisheries No. PER.13 / MEN / 2005 on the Crime Management Coordination Forum Fisheries, as last amended by PER.18 / MEN / 2011;

- Regulation of the Minister of Marine Affairs and Fisheries No. PER.04 / MEN / 2006 on the Establishment of Technical Implementation Unit (UPT) Monitoring SDKP;
- Regulation of the Minister of Marine Affairs and Fisheries No. PER.19 / MEN / 2006 concerning the appointment of the harbor master at the Port of Fisheries;

- Regulation of the Minister PER.27 / MEN / 2009 on Fishing vessels;

- Regulation PER.18 / MEN / 2010

4. Marine and Fisheries Number on Registration and Marking of Marine and Fisheries Number of Fishing Log Book;

5. Regulation of the Minister PER.14 / MEN / 2011 as amended by PER.49 / MEN / 2011;

6. Regulation of the Minister PER.08 / MEN / 2012

7. Regulation of the Minister PER.12 / MEN / 2012 the high seas;

8. Regulation of the Minister PER.13 / MEN / 2012 Fish;

9. Decision of Directorate General of Marine and Fish 
Resources Surveillance

PSDKP / 2012 on Technical

Guidelines for Operational

Control of Fishing Vessels.

Indonesia's action plans:

Indonesia is currently preparing several laws, including :

1. Finalization of Government Regulation on Fisheries Control draft;

2. Preparation of draft materials on Government Regulation on the Award for Law Enforcement Officials and Parties Participating in Rescue Efforts of State Assets;

3. Draft material of Regulation for Vessel Monitoring System to observe fishing vessels' activities;

4. Attempt to regulate the use of electronic evidence in criminal acts fisheries management in the legislation;

5. Improvement for the Minister of Marine and Fisheries Regulation No. PER.05 / MEN / 2007 on the Implementation of Fisheries Vessel Monitoring System which regulates the implementation of the Vessel Monitoring System (VMS).

\section{b. Nation-wide Control}

Recommendation of IPOA-IUU Fishing

States should, to the extent possible in their national law, avoid conferring economic support, including subsidies, to companies, vessels or persons that are involved in IUU fishing.

Associated with the provisions of the IPOA which requires each state to regulate fishing activities in order to prevent IUU fishing, Indonesia has set:

1. Law No. 31 of 2004 on Fisheries, as amended by Law No. 45 of 2009;

2. Law No. 17 Year 2008 on the voyage, which provides that:

a) Vessels from Indonesia flag is required to fly Indonesian flag as a sign of vessel's nationality

b) Non-Indonesian vessels are forbidden to sail with Indonesian flag

c) Ships sailing in the waters of Indonesia 
with more than one flag as a sign of nationality, are considered not to have the identity of the ship.

3. Regulation of the Minister of Marine Affairs and Fisheries No. PER. 14 / MEN / 2011 on Business Fisheries, as amended by Regulation of the Minister of Marine Affairs and Fisheries No. PER. 49 / MEN / 2011

In addition, Indonesia has made efforts to prevent the practice of IUU fishing by fishing vessels and fish transport vessels which perform activities in other countries or jurisdictions inside the conservation area of regional fisheriesmanaging organizations. The operational measures undertaken include ${ }^{11}$ :

1. Cooperation between Indonesia and Australia in Indonesian-Australian

Fisheries Surveillance Forum;

\footnotetext{
${ }^{11}$ Adrianto, Implementation of Code of Conduct for Responsible Fisheries in the Perspective of Developing Countries, Indonesia Journal of International Law, 2005, 2 (3): 463-482.
}

2. Patrol cooperation between Malaysia-Indonesia (cooperation between states);

3. Socialization to those who are involved in fisheries business;

4. Improvement of surveillance; and

5. Consistent law enforcement.

\section{Indonesia's action plan:}

For the foreseeable future, the Government of Indonesia will take the following steps:

a.Adjust the various laws and policies in Indonesia which are related to the prevention and control of IUU fishing by fishing vessels and fish transport vessels; so as to comply with international regulations;

b. Improve surveillance of all fishing vessels and fish transport vessels in Indonesia.

\section{c. Vessels without Nationality}

Recommendations of IPOA-IUU Fishing: 
States should ensure that fishing vessels entitled to fly their flag do not engage in or support IUU fishing.

Indonesia has to prevent the entry of vessels without nationality from taking advantage of ports in Indonesia or getting a fishing license in Indonesia. Pursuant to Article 166 paragraph (1) of Law No. 17 Year 2008 on the Voyage, any ship sailing in Indonesian waters must indicate clearly the identity of the ship.

Indonesia's action plan:

a. Anticipate the entry of vessels without nationality which perform fishing from the high seas to Indonesia, with operational optimization of surveillance vessels;

b. Improve the quality of fish resources supervision;

c. Coordination with relevant agencies, among others, the water police and Navy (TNI).

\section{d. Sanction}

Recommendations of IPOA-IUU Fishing

States should ensure that sanctions for IUU fishing by vessels and, to the greatest extent possible, nationals under its jurisdiction are of sufficient severity to effectively prevent, deter and eliminate IUU fishing and to deprive offenders of the benefits accruing from such fishing. This may include the adoption of a civil sanction regime based on an administrative penalty scheme. States should ensure the consistent and transparent application of sanctions.

Indonesia has set strict sanctions against the perpetrators of IUU fishing in Indonesia, as stipulated in:

1. Law No. 31 of 2004 on Fisheries, as amended by Law No. 45 of 2009;

2. Law Number 17 Year 2008 on the voyage.

Indonesia has imposed sanctions against the perpetrators of IUU fishing in forms of imprisonment and fines, and the confiscation of evidence boats and fishing gear by the state.

\section{Indonesia's action plans:}

Indonesia will continue to improve consistency and transparency in 
implementing the sanctions for the perpetrators of IUU Fishing.

\section{B. Possible Taken Actions By Indonesia's Government to Prevent Illegal}

Fishing/Poaching by Foreign-

Flagged Vessels in The

Exclusive Economic Zone

There are several factors that cause many perpetrators of IUU Fishing, namely:

1. The rise of illegal fisheries-an indication that illegal acts are more economicallyadvantageous than legal fishing.

2. Higher legal costs-if the legal costs are higher than illegal revenues, then the illegal fishing activity is not likely to happen

3. The net gain of illegal fishing is higher than the net profit of legal fisheries

4. The level of fish consumption in Indonesia is increasing

5. Fish resources in other countries are on the wane
6. Lack of supervisory authorities in the Indonesian sea. ${ }^{12}$

In other words, the perpetrators feel that illegal fishing results in much higher profits compared to legal fishing. In addition, there are also adverse effects caused by IUU fishing activities in Indonesia, such as these following: ${ }^{13}$

1. The threat to the conservation of fish resources;

2. The decline of livelihoods of local fishing communities with small-scale fishing fleet and simple fishing gear, because they cannot compete with those performing illegal fishing;

3. The loss suffered by majority of fish production industries and loss of opportunities to improve national economy;

4. Reduction of Non-Tax Revenues;

5. Inhibition of Indonesia's efforts to strengthen the fish processing industry in the

\footnotetext{
${ }^{12}$ Theft of fish by foreign ships in waters Based on the Exclusive Economic Zone Law No. 31 Year 2004 on Fisheries Accessed on http://elib.unikom.ac.id/files/disk1/646/jbptunikompp -gdl-andihidaya-32274-9-unikom_a-v.pdf pada tanggal 23/09/2015 at19.18

${ }^{13}$ Contained in the Ministerial Decree No. KEP / 50 / MEN / 2012 Chapter III point D
} 
country, including the effort to improve competitiveness;

6. Damage to the image of Indonesia in the international arena done by foreign vessels that use the Indonesian flag or vessels owned by Indonesian citizens and conducting illegal fishing, contrary to international conventions and agreements. It can also trigger the threat of embargo on the Indonesian fishery products marketed abroad.

Given these factors and the bad impacts of illegal fishing in the coastal State, in accordance with the points exposed previously, Indonesia has developed an enforcement mechanism in form of the sinking of foreign-flagged illegal fishing vessels. However, this mechanism can lead to hostility between Indonesia and other countries. To avoid this, Indonesia should make the sinking of illegal foreign fishing vessels as the last alternative of the sanctions for illegal fishing.

Thus, to prevent and crack down on illegal fishing activities that cause harm to both countries, the author will mention and explain some of the efforts that can be made by the Indonesian government to prevent the aforementioned violations. By implementing these, hopefully the occurrence of illegal fishing in Indonesia by fishing vessels foreign-flagged fishing can be reduced.

\section{The role of marine and fisheries diplomacy}

Advanced Oxford Dictionary 2003 describes diplomacy as "the management of international relations through negotiation, which is harmonized and regulated by the ambassadors and representatives; business or art diplomats from the country". If you see a great sense of diplomacy by Indonesian dictionary, then diplomacy involves four (4) following case: ${ }^{14}$

a. Affairs or the organization of official nexus between countries;

b. The interests of a country's affairs through their representatives in other countries;

\footnotetext{
${ }^{14}$ Bayu Vita, sonny and Freshty.2014, the diplomatic role of marine and fisheries as part of efforts to tackle illegal fishing in Indonesia, (online) accessible from http://bbpse.litbang.kkp.go.id/publikasi/jbijak/jurbija k_2013_v3_no1_\%284\% 29_full.pdf on 09/26/2015 at $14: 39$
} 
c. Knowledge and skills in terms of the nexus between countries; and

d. Proficiency in using wellchosen words for the benefit of the authority (in negotiations, answering questions, expressing opinions, etc.).

Etty R. Agoes, stated her opinion associated with the handling or reduction of IUU fishing ${ }^{15}$, which is a form of international interstate (transnational) crime: one of the steps that needs to be done by the Ministry of Maritime Affairs and fisheries (MMAF) is diplomacy related to the plan of action related to the issues and problems of illegal fishing.

Diplomacy needs to be done to provide data and information relating to other forms of violations of illegal fishing which has been carried out by foreign nations to countries of their origin, with the aim of realization of compliance to the regulations imposed in Indonesia in the fight against illegal fishing done by perpetrators from other countries. The bilateral and multilateral

${ }^{15}$ Etty R Agoes, an expert in international maritime law Faculty of Law, University of Padjadjaran Bandung, during the "Focus Group Discussion Study of Legal Aspects in the Context of Combating IUU Fishing in Indonesia in Jakarta, December 10, 2012", establishments need to reach an understanding in handling illegal fishing. For example, in violations committed by Indonesian fishermen in the country, the government can use the data of previous violation as a supporting tool to defend Indonesian fishermen; or the Indonesian government can give the excuse that Indonesian fishermen do the violation because the fish resources in Indonesia have also been stolen by fishermen from other countries. ${ }^{16}$

\section{By adding and enhancing the law enforcement agencies}

Law enforcement agencies are those that are directly or indirectly involved in the legal field. They are the ones in charge in the field of the judiciary, prosecutorial, police, and correctional institutions. Soerjono Soekanto stated that law enforcement has an ideal role as well as an actual role (a role that is actually done). This determines the role of a law enforcement unit in doing its job. Therefore, the author argues that the law enforcement fleets have an indispensable role in maintaining the

\footnotetext{
${ }^{16}$ Bayu vita, Sonny and Freshty, Op Cit.
} 
security of the jurisdiction of the Indonesian territorial waters.

\section{Improving the Supporting Facility} of the Law Enforcement Agencies

Facilities and amenities include educated manpower, adequate equipment, adequate financing which enables and supports the ongoing process of law enforcement, as if this is not met, then it is impossible to reach the goal of law enforcement ${ }^{17}$. been announced by the government of the Republic of Indonesia must be sustainable, the problem of IUU fishing is not a seasonal problem but one that requires ongoing treatment. If Indonesia wants to impose sanctions in form of sinking of the illegal foreign fishing vessel, it should be done only if other methods have been attempted, such as diplomacy, improvement of the facilities and amenities. It would be more agreeable if the sanction to foreign-flagged fishing vessels is done only as a last resort (ultimum remedium).

\section{REFERENCES}

The Indonesian government has launched a national action plan for prevention of IUU fishing as mandated by international legal instruments. The legal actions that can be done by Indonesia to prevent illegal fishing carried out by foreign-flagged fishing vessels are: conducting diplomacy in marine and fishery fields, adding law enforcement fleets, improving infrastructure and facilities to support law enforcement, making vesselsinking sanction as the last resort (ultimum remedium).

The anticipation of IUU fishing in the form of national action plans that have

\footnotetext{
${ }^{17}$ Bayu vita, Sonny and Freshty, Ibid
}

\section{Book}

Begi Hersutanto, The True Meaning Island States, Maritime Security Coordinating Board, Jakarta, 2009.

Dr. Ir. Victor PH Nikijuluw, SocioEconomic Dimensions of Fisheries Illegal (Blue Water Crime), Jakarta, Cidesindo 2008.

I Wayan Parthiana, International Maritime Law and Law of the Sea Indonesia, Bandung: Yrama Widya, 2014.

Joko Subagyo, Law of the Sea of Indonesia, Jakarta, Rineka Copyright 2002.

Mochtar Kusumaatmadja, Introduction to International Law, Alumni, Bandung, 2003.

Telly Wick, et al. General Dictionary of Politics and Law, Jakarta: Jala Jewel Script 2010.

Soehino, Science of the State (Yogyakarta: Liberty, 1980) points: 17 
Wahyono Suroto Kusumoprojo, Maritime State of Indonesia, Jakarta: Mizan Publika 2009.

\section{Journal}

Adrianto, Implementation of Code of Conduct for Responsible Fisheries in the Perspective of Developing Countries, Indonesia Journal of International Law, 2005, 2 (3): 463482.

Ariatno, Indonesia Interest In Free Marine Fisheries Management, Indonesia Journal of International Law, 2005, 2 (3): 503-544.

Johanis Leatemia, The Legal Regulations of Regional Islands, Pulpit Law, Volume 23, No. 3 (October 2011), p. 431.

\section{Convention and National Laws}

Law No. 45 of 2009 on the Amendment of Law No. 31 Year 2004 on Fisheries.

Law No. 6 of 1996 About Water Management.

Law of the Republic of Indonesia Number 17 of 1985 RATIFICATION OF THE UNITED NATIONS CONVENTION ON THE LAW OF THE SEA (UNITED NATIONS CONVENTION ON THE LAW OF THE SEA).

Law No. 5 of 1983 on the Indonesian Exclusive Economic Zone (ZEEI).

Decree of the Minister of Marine and Fisheries of the Republic of Indonesia Number KEP.50 / MEN / 2012 on the National Action Plan for the Prevention and Combating IUU from 2012 to 2016.

United Nations Convention on the Law of the Sea 1982.

International Plan of Action to Prevent, Deter and Eliminatee Illegal, Unreported and Unregulated Fishing (IPOA-IUU).
FAO Code of Conduct for Responsible Fisheries.

Rome Declarations on IUU fishing. 